\title{
The importance of Professor Américo Piquet Carneiro for health in Brazil
}

The begining of September 2019 will mark the $110^{\text {th }}$ anniversary of the birth of Américo Piquet Carneiro, a native of the state of Ceará, who came to Rio de Janeiro at the age of five, graduated in medicine at the National School of Medicine in 1934, and embarked on a career as doctor and teacher and a maker of dreams so increasingly publicly-focused that almost all became reality. Those who had the privilege of knowing Professor Piquet - a she was affectionately known by all - especiallyin the final years of his life, will recall the last of those dreams: the implantation of the Care Center for the Elderly (or NAI) within the Pedro Ernesto University Hospital and the creation of the Open University of the Third Age (UNATI) within the framework of his beloved UERJ. Anyone familiar with teaching hospitals in public universities, which are in an almost constant state of crisis, will understand the difficulties involved in the creation of the NAI, the embryo of UNATI, which included securing a physical space for the new operation and the hiring of staff, a task made more complicated by the pioneering multi- and interdisciplinary approach of the project. This entire process was led by a professor who had been retired for more than ten years, was already over 80 years of age, and whose passionately held motto was "what will happen in Brazil in 2025, when we have the sixth biggest elderly population in the world, with more than 30 million people". For Professor Piquet the title of "Professor Emeritus", which for many represents just another honorable recognition from the university from which they retire, was merely a passport to manufacture more dreams... and how he manufactured them! The Care Center for the Elderly was born! It emerged as a fragile little plant among leafy trees, then added emotions and hearts, and was watered by the hopes of young professionals and the expectations of the elderly who taught them, day after day, that life is about coming together! The dream was then expanded to the University, in the shape of the UNATI project, a more complex leap, perhaps into calmer waters, perhaps not! At a more advanced age, with lessened vigor, but with courage and faith preserved! Américo Piquet Carneiro did not live to see the inauguration of UNATI, passing away a few months before, but the ingredients and arrangements for its creation were all chosen and orchestrated by him.

How did he achieve all this? How did he manage to transfer the Pedro Ernesto Hospital- the "cherry on the cake" of the hospital network of the Health Department of the newly created state of Guanabara - to a young university that was changing its name for the third time? How did he organize the construction, for the transfer of basic courses, of the building that today bears his name, physically guaranteeing alink with the Hospital? How did he plan and set up an Integral Medicine Outpatient Clinic at a time when the emphasis was on rapid specialization? How did he live, with so much pain, but without losing his composure, through one of the saddest moments in the history of the college of which he was the director, the death of Luiz Paulo and the injuries to several other students on October 22, 1968? How did he manage to conceive and create the Institute of Social Medicine in the darkest days of the military regime? We could list other 
achievements, such as the incorporation of the Rachel Haddock Lobo Nursing School into the then Guanabara State University, the creation of the Biological Sciences Course and the Roberto Alcântara Gomes Institute of Biology, the establishing of the first master's degrees in health and the Piquet Carneiro Health Clinic, all of which should only increase our sense of wonder at someone who managed to accomplish all this in a generation, without ostentatiously wielding power, without explicitly currying favour with politicians, without making demands on alumni and patients in influential positions, without raising his voice, without ever exhibiting any sorrow or resentment at the considerable difficulties he faced. Given the diversity and the volume of his achievements, a simple interpretation is almost impossible. Maybe we can think of some possibilities based on how he presented himself to the world. First, the books! Most of those who knew him say that he almost always walked around with books, often giving them away like a farmer tosses seeds to the ground, without asking whether they will grow or not! Secondly, knowledge! His almost obsession-like need to seek out new knowledge, from an era in which Immunology was still a mere appendage of Microbiology in a textbook, included proposing that environmental health officers have sufficient knowledge in the field, and the recommendation that oncologists and geriatricians study inflammatory processes in more depth, as well as insisting on greater knowledge of the connective tissue structure. And finally there were his actions! It was a constant theme of his life, to act silently and patiently, with frank and transparent goals, to carry out actions whose essential characteristic was to empower people, from his most qualified pupil to the humblest employee, from the most important media figure to the most anonymous worker, all seemed to be left with the same sense of belonging, the feeling of being part of a network where everyone was of equal importance and had the same power to achieve an objective which then became something of value for everyone. But how could he make reading, knowledge, and action such an effective equation? Perhaps because of his capacity to engage in dialogue, expressed by an always kindly attitude to people and a way of listening carefully to them, perhaps because of his ability to devote himself to a cause, the gift of himself, perhaps because of his faith, which went much further than the religious - which he carried with him as well - the faith he had in people, in the sense that they all have deep within their being the desire and intention to do things that are greater than themselves and that surpass their existence...

Francisco Barbosa Neto

Former Director General of Pedro Ernesto University Hospital of the Rio de Janeiro State University (UERJ) and Faculty Member of the Department of Integral, Family and Community Medicineof the UERJ School of Medical Sciences. Rio de Janeiro, Brazil.

E-mail: chibarnet@gmail.com 